Proceedings

\title{
Role of Non-pharmaceutical Interventions (NPIs) During COVID-19 Pandemic: A Systematic Literature Review
}

\author{
Su Peng Chua ${ }^{1}$, Faiz Daud ${ }^{{ }^{*}}$ and Normaslina Mustaza ${ }^{1}$ \\ 1 Department of Community Health, Faculty of Medicine, University Kebangsaan Malaysia, 56000, Cheras, \\ Kuala Lumpur, Malaysia; hiraishin@gmail.com, faizdaud@ppukm.ukm.edu.my and masyihi- \\ mura79@gmail.com \\ * Correspondence: faizdaud@ppukm.ukm.edu.my; Tel.: +6019-2712008
}

Publisher's Note: MDPI stays neutral with regard to jurisdictional claims in published maps and institutional affiliations.

\section{(c) (1)}

Copyright: (C) 2021 by the authors. Submitted for possible open access publication under the terms and conditions of the Creative Commons Attribution (CC BY) license (http://creativecommons.org/licenses/by/4.0/).

\begin{abstract}
Background: Non-pharmaceutical interventions (NPIs) as a means of prevention during the COVID-19 pandemic have gained increasing attention. NPIs are important to reduce infectious disease and flatten the curve of infection. However, data or literature on the effectiveness of NPIs is scarce. In this review, we aim to investigate the effectiveness of NPIs in the community based on previous literature. Methods: A literature search was conducted on seven databases (OVID, EBSCOHOST, WOS, SCOPUS, TRIP, JSTOR, and PUBMED) using the PICO method which yielded 208 articles. A PRISMA flow diagram and extraction tables were used to analyze the final 14 eligible articles spanning nine countries. Results: There were nine articles on human surveillance, two on patient and contact management, two on community restrictions, and one article discussing the combination of NPIs (quarantine, closure of facilities, and transit site surveillance). With the use of NPIs, there was a significant reduction of infection episodes among the target population. Conclusions: There has been an increasing demand for scientific evidence on NPIs during the COVID-19 pandemic, and present policy recommendations rely heavily on expert judgement. Randomized trials are required to obtain better evidence for these interventions. However, in the absence of definitive evidence, this review will help experts create feasible and widely acceptable policies and protocols for mitigation plans.
\end{abstract}

Keywords: COVID-19 pandemic; cough etiquette; hand hygiene; quarantine; closure of facilities; face mask; PPE

\section{Introduction}

As of June 4, 2020, severe acute respiratory syndrome coronavirus 2 (SARS-CoV-2), or otherwise known as COVID-19, has affected more than 6.56 million individuals worldwide and caused more than 387,987 deaths ${ }^{1}$. The World Health Organization (WHO) has declared the pandemic as a Public Health Emergency of International Concern (PHEIC) on January 30, 2020². Governments across the globe quickly implemented emergency lockdowns in their respective countries to help flatten the curve of infection. With the unavailability of effective vaccines, non-pharmaceutical interventions (NPIs) have been given serious attention to prevent and curb COVID-19 transmission. Numerous unknown factors, such as the distance of infective spread and the mode of transmission, have thrown a curveball to scientists. Some argue that the infection is spread via aerosolized droplets, whereas some state that it is airborne. Nevertheless, until an effective vaccine or treatment intervention becomes available, COVID-19 prevention will continuously rely on NPIs, including pandemic mitigation in the community ${ }^{3}$. To prevent the disease from spreading and to reduce morbidity and mortality among the public, policymakers have introduced conflicting advice on physical and social distancing. Besides, the use of N95 respirators and face masks have been controversial, especially when personal protective 
equipment (PPE) shortages arose. Among the other implemented NPIs include self-quarantine, isolation of ill individuals, cough etiquette, hand hygiene, and the use of $\mathrm{PPE}^{4}$. NPIs are important to reduce infectious disease and flatten the curve of infection. However, data or literature on the effectiveness of NPIs is scarce. In this review, we aim to determine the effectiveness of NPIs in the community based on previous literature.

\section{Methodology}

A total of 208 scientific articles were identified after an extensive search on several databases (TRIP, OVID, EBSCOHOST, WOS, SCOPUS, JSTOR, and PUBMED) using NPIs search terms. Other search terms included people with WHO-defined confirmed or probable COVID-19, MERSCOV, SARS, or influenza-like illnesses (ILI). Close contacts to the index cases were also accounted for. NPIs such as one-meter social distancing, quarantine, use of a face mask or N95 respirators, proper hand hygiene and cough etiquette, and closure of facilities were also included. Various combinations of the Medical Subject Headings (MeSH) were searched for in the databases from the year 2000 [Supplementary File 1: S1] using the PICO method ${ }^{5}$. The inclusion criteria were the English language, peerreviewed articles from the year 2000 to 2020. The exclusion criteria were animal studies and systematic reviews. A flow diagram of Preferred Reporting Items for Systematic Reviews and Meta-Analyses (PRISMA) (Figure 1) was created ${ }^{6}$. From the search, we identified 208 titles, 14 (across nine countries) of which were eventually selected based on general relevance and compatibility [Supplementary File 2: S2]. Titles and abstracts were screened at the initial search. The full text of the articles was reviewed, and the data were extracted into pre-piloted forms in MS Excel. To avoid the risk of bias, two authors independently assessed the articles. Disagreements were resolved by discussion and consensus. Data were extracted by study identifier, study design, setting, population, intervention and comparator characteristics, main outcomes, and findings.

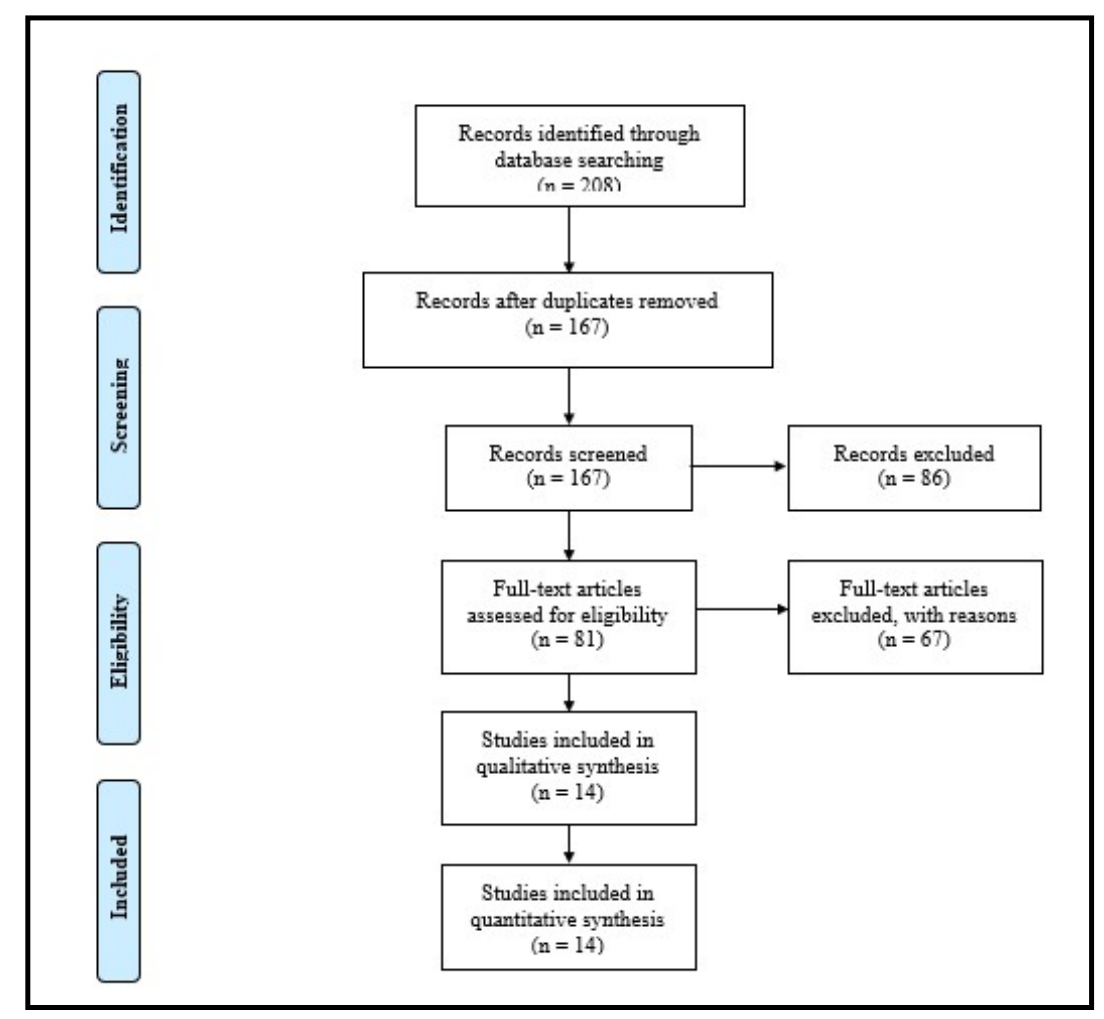

Figure 1. Prisma Diagram showing the results of the literature search ${ }^{6}$. 
The NPIs ascertained through our database search include (i) human surveillance, (ii) patient and contact management, and (iii) community restrictions (Table 1).

Table 1. Non-pharmaceutical interventions (NPIs) during influenza outbreaks ${ }^{7}$.

\begin{tabular}{|c|}
\hline 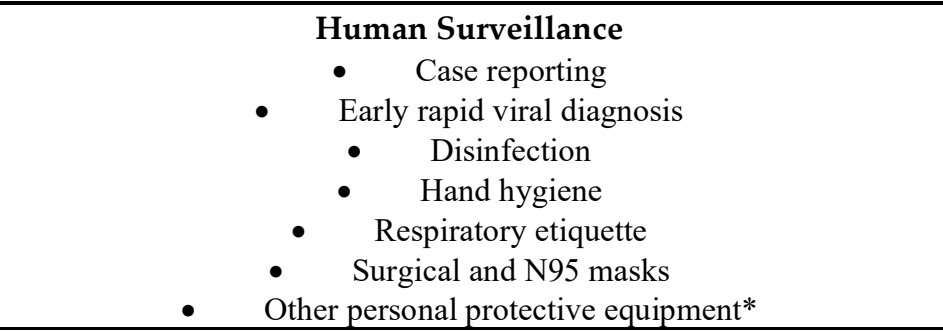 \\
\hline $\begin{array}{c}\text { Patient Management } \\
\text { - Isolation of sick individuals } \\
\text { Provision of social support services to the isolated }\end{array}$ \\
\hline $\begin{array}{l}\text { Contact Management } \\
\qquad \quad \text { Quarantine** } \\
\qquad \quad \text { Voluntary sheltering*** } \\
\qquad \quad \text { Contact tracing } \\
\end{array}$ \\
\hline $\begin{array}{c}\text { Community Restrictions } \\
\bullet \quad \text { School closures } \\
\bullet \quad \text { Workplace closures } \\
\text { - } \quad \text { Cancellation of group events } \\
\end{array}$ \\
\hline $\begin{array}{c}{ }^{*} \text { Gowns, gloves, and protective eye covers } \\
* * \text { Separation of exposed individuals from others } \\
* * * \text { Voluntary sequestration of healthy persons to avoid exposure } \\
{ }_{* * * * \text { Exit and entry screening, travel advisories }}\end{array}$ \\
\hline
\end{tabular}

\section{Results}

\subsection{Human Surveillance}

A total of nine articles were identified, which involved hand hygiene, respiratory etiquette, and use of face mask in community settings ${ }^{4,8-16}$. The studies are presented in Table 2 based on their results, applicability, and limitations as there were vast differences in the study design, participants, and interventions.

Of the nine studies, four were conducted in school settings, in which the outcome of the intervention was measured by the number of total absent days and numbers of secondary infections. A 3-year quasi-experimental study conducted by Apisarnthanarak et al. in Thailand found a significant reduction in laboratory-confirmed influenza infection which was associated with the practice of hand hygiene and cough etiquette among preschoolers, $60.8 \%$ in period $2(\mathrm{p}=0.008)$ and $19 \%$ in period $3(\mathrm{p}=0.002)^{8}$. A similar intervention performed by Stebbins et al. which measured a randomized controlled trial among elementary school students in the USA showed that there was no significant effect of the intervention on the primary study outcome of all laboratory-confirmed influenza cases (incidence rate ratio [IRR] 0.81; 95\% confidence interval [CI] 0.54-1.23). However, the study revealed a statistically significant difference in protocol-specified ancillary outcomes in which a significant reduction in laboratory-confirmed influenza A infections was observed among children in intervention school compared with those in control schools, with an adjusted IRR of 0.48 (95\% CI 0.26-0.87). Moreover, the study demonstrated a significant reduction in total absent days among the intervention group compared with the control group, with an adjusted IRR of 0.74 (95\% CI 0.56-0.97) ${ }^{14}$. A few randomized controlled studies were conducted among households to assess the involvement of hand hygiene with the usage of face masks. The studies conducted by Cowling in Hong Kong 
found no significant difference between the intervention group and the control group. Nevertheless, a reduced transmission among influenza confirmed cases to contacts in the intervention group was observed (adjusted OR, 0.33 [95\% CI 0.13-0.87]) .

Two other studies conducted by Aiello et al. and Seuss et al. also found a significant reduction in secondary infection in the intervention group compared with the control group $^{4,13}$. However, the study by Simmerman found no significant difference in terms of secondary infection in the hand hygiene group $(\mathrm{OR}=1.20 ; 95 \% \mathrm{CI} 0.76-1.88 ; \mathrm{p}=0.442)$ or the hand hygiene and face mask group $(\mathrm{OR}=1.16 ; 95 \% \mathrm{CI} 0.74-1.82 ; \mathrm{p}=0.525)^{12}$.

Three studies were conducted to evaluate the effectiveness of hand hygiene. A randomized controlled trial conducted by Talaat et al. in Egypt included 20,882 school children who were divided into the intervention arm and control arm. In this trial, a significant decrease in the amount of absenteeism (reduced by $40 \%, \mathrm{p}<0.0001$ ) and laboratoryconfirmed influenza (reduced by $50 \%, \mathrm{p}<0.0001)^{15}$ was found. Another study conducted by Lau et al. revealed that the percentages of total absent days and illness-related absent days were significantly lower in the intervention group during the flu season $(p=0.002$, $\mathrm{p}<0.001$, respectively). The difference was significant during the influenza season but declined in the following months ${ }^{11}$. Finally, Savolainen-Kopra concluded that hand hygiene, with the use of water and soap, was associated with reduced influenza infection (reduced by $6.7 \%, \mathrm{p}=0.04)^{16}$.

\subsection{Patient and Contact Management}

Two observational studies that evaluated the effectiveness of quarantine during the SARS outbreak in Taiwan in 2003 (Table 3) were identified. A study by Hsieh et al. found that quarantining contacts that were potentially exposed to suspected SARS patients (Level A quarantine) prevents approximately 461 additional cases of SARS and 62 additional deaths, as compared with quarantining travelers from SARS-infected areas (Level B quarantine) ${ }^{17}$. A study conducted by Wang supported Hsieh's findings. They both found that people who are potentially exposed to suspected SARS patients have a three times higher risk of developing SARS compared with travelers from SARS-infected areas. Wang also stated that only people with known exposure to persons infected with SARS could reduce the number of people that needed to be quarantined by $64 \%{ }^{18}$.

\subsection{Community Restriction}

Two observational studies on school closure during the influenza outbreak in Israel and Australia (Table 4) were conducted. A study by Heymann found a statistically significant difference in the weekly ratio of influenza-like diagnoses to non-respiratory diagnoses $(p=0.0074)$ during school closure compared with other years ${ }^{19}$. A survey on 233 parents in Perth, Australia, revealed that $47 \%$ thought the school closure was appropriate, $33 \%$ thought it was inappropriate, and $20 \%$ did not respond. During the school closure, only six cases reported that fulfillment of the case definition for ILI indicates the effectiveness of school closure during influenza outbreak ${ }^{20}$.

\subsection{Combination}

Finally, Bartlett ${ }^{21}$ investigated the effects of quarantine, closure of facilities, and transit site surveillance during the SARS outbreak in Beijing in 2003 (Table 5). An estimated number of around 2,610 public schools; public entertainment, such as theatres, bars, and libraries; and indoor sports facilities were closed from April 24, 2003, until early July 2003. From his observation, around 2,195 close contacts were quarantined. The attack rates were $6.3 \%$ (95\% CI 5.3\%-7.3\%), with a range of $15.4 \%$ (95\% CI $11.5 \%-19.2 \%$ ) among spouses to $0.36 \%(95 \% \mathrm{CI} 0 \%-0.77 \%)$ among work and school contacts. He found that the attack rate increased as the age of the group increased. The attack rates were 5.0\% (95\% CI $0 \%-10.5 \%$ ) in children younger than 10 years and $27.6 \%(95 \%$ CI $18.2 \%-37.0 \%)$ in adults aged 60 to 69 years. Through transit site screening, only 12 out of 14 million individuals 
who were screened for fever were found to have probable SARS. The time lag between illness onset and hospitalization decreased from a median of 5-6 days on or before April 20, 2003 (the day the outbreak was announced to the public), to 2 days after April 20 ( $\mathrm{p}<$ $0.001)^{21}$.

\section{Discussion}

In our review, there was limited evidence to support the effectiveness of NPIs in reducing the transmission of the influenza virus during outbreaks. It is important to determine which public health interventions would be effective as preventive measures to mitigate the influenza pandemic. NPIs such as hand hygiene, respiratory etiquette, face mask, and PPE could be most effective in short-distance transmission, either through direct or indirect contact. More comprehensive precautions are required to prevent the spread of disease in larger groups of people, such as isolation of sick people, quarantine of close contacts, closure of facilities, massive screening, restrictions of domestic and international travels, and cancellation of group events.

In a recent review by Bankston, it was concluded that influenza transmission among human beings occurs generally in short rather than long distances ${ }^{22}$. This emphasizes the importance of personal prevention in reducing the spread of infectious diseases within the community. Most of the infections that occurred caused an increase in absenteeism in schools and workplaces. Further evidence revealed that the substantial benefit of hand hygiene to prevent influenza transmission ${ }^{11,15,16}$ is suggestive for direct or indirect contact as one of the most important modes of transmission. Furthermore, the effectiveness of combining personal prevention (hand hygiene, cough etiquette, and face mask) indicated ${ }^{4}$ $8,9,13$ that the interventions were able to reduce infections. However, there have been growing concerns about the implementation of the closure of facilities as it will negatively impact the socioeconomic status of the community ${ }^{20}$. Nevertheless, NPIs have resulted in major improvements in containing the spread of infectious diseases based on the available data and their outcomes.

The effectiveness of the NPIs was probably impacted by the compliance issues in the community ${ }^{12,20}$. Various studies revealed low or non-compliance to NPIs ${ }^{12,} 20$ or low acceptance among the communities. Thus, further research is required to investigate the influence of cultural and socio-behavioural factors on the levels of compliance to NPIs during a pandemic. For example, the use of face masks is more common during the SARS epidemic in Hong Kong than in Singapore ${ }^{23}$. This may be due to the differences in culture, which will also affect the implementation of NPI policies. Due to a lack of evidence of other forms of NPIs, such as cancellation of group events and restrictions of international and domestic travels, further research is needed to determine the effectiveness of NPIs as part of the mitigation strategy of public health. The use of disinfectants as personal prevention is also important, but due to lack of research or literature, it is less encouraged as part of the prevention method during a pandemic. Pandemic guidelines provided by the WHO and the US Centers for Disease Control and Prevention (CDC) have clearly outlined various methods for implementing NPIs to enhance its effectiveness in containing infectious diseases, especially during influenza outbreaks, such as COVID-1924, 25. The strengths of our review include a comprehensive literature search before the selection of articles and critical discussion of the findings which comprise wide coverage of NPIs that have been commonly used during the outbreak and related to the current situation. However, the primary limitation of our study is that during our review, articles related to the application of NPIs during the COVID-19 outbreak were lacking, which lead us to focused more on NPIs use during the influenza pandemic.

\section{Conclusion}


While waiting for new pharmacological treatment for COVID-19 and effective vaccines, this systematic review further reaffirms the need for NPIs to curb influenza transmission and to prevent further spread. Human surveillance, patient, and contact management as well as community restriction play significant roles in combating this pandemic. The demand for scientific evidence of NPIs during the influenza pandemic is imminent. Expert judgments on NPIs that are likely to be beneficial, feasible, and socially acceptable during outbreaks will guide policymakers in creating future guidelines and protocols. These findings should be considered while creating national, state, local, or facility epidemic mitigation plans. Further studies to evaluate the impact of NPIs to reduce the cases of ILI or Severe Acute Respiratory Infection (SARI) in the community will contribute to the promotion of public health and preparedness planning for emerging infectious diseases.

Table 2. Summary of the nine articles under human surveillance.

\begin{tabular}{|c|c|c|c|c|c|c|}
\hline Study & Setting & $\begin{array}{c}\text { Participants and } \\
\text { follow-up }\end{array}$ & Study design & $\begin{array}{c}\text { Interventions } \\
\text { evaluated }\end{array}$ & Main outcomes & Findings \\
\hline $\begin{array}{l}\text { Aiello et al., } \\
2012\end{array}$ & $\begin{array}{l}5 \text { university } \\
\text { residence hall, } \\
\text { Michigan } \\
\text { University, USA }\end{array}$ & 1178 individuals & $\begin{array}{l}\text { Randomized } \\
\text { intervention } \\
\text { trial }\end{array}$ & $\begin{array}{l}\text { Hand hygiene, } \\
\text { face mask, and } \\
\text { control group }\end{array}$ & $\begin{array}{l}\text { Incidence of ILI } \\
\text { cases }\end{array}$ & $\begin{array}{l}\text { Significant } \\
\text { reduction in the } \\
\text { rate of ILI in the } \\
\text { intervention } \\
\text { group as } \\
\text { compared with } \\
\text { the control } \\
\text { group }\end{array}$ \\
\hline $\begin{array}{c}\text { Apisarnthanara } \\
\text { k et al., } 2009\end{array}$ & $\begin{array}{l}\text { Private Thailand } \\
\text { Kindergarten }\end{array}$ & 240 children & $\begin{array}{l}\text { Quasi- } \\
\text { experimental } \\
\text { study }\end{array}$ & $\begin{array}{c}\text { Hand hygiene } \\
\text { and cough } \\
\text { etiquette }\end{array}$ & $\begin{array}{c}\text { Incidence of ILI } \\
\text { cases }\end{array}$ & $\begin{array}{c}\text { Significant } \\
\text { reduction of } \\
\text { cases in period } 2 \\
\text { and period } 3\end{array}$ \\
\hline Cowling, 2009 & $\begin{array}{l}45 \text { outpatient } \\
\text { clinics in the } \\
\text { private and } \\
\text { public sectors in } \\
\text { Hong Kong }\end{array}$ & 794 households & $\begin{array}{c}\text { Cluster- } \\
\text { randomized } \\
\text { controlled trial }\end{array}$ & $\begin{array}{l}\text { Hand hygiene, } \\
\text { hand hygiene } \\
\text { plus surgical } \\
\text { face mask, and } \\
\text { control group }\end{array}$ & $\begin{array}{l}\text { rT-PCR- } \\
\text { confirmed } \\
\text { influenza } \\
\text { infection }\end{array}$ & $\begin{array}{c}\text { Significant } \\
\text { fewer infection } \\
\text { cases in the } \\
\text { intervention arm } \\
\text { compared with } \\
\text { the control arm }\end{array}$ \\
\hline Lau et al., 2012 & $\begin{array}{c}2 \text { Chicago Public } \\
\text { Elementary } \\
\text { Schools }\end{array}$ & 981 students & $\begin{array}{l}\text { Prospective } \\
\text { cohort study }\end{array}$ & $\begin{array}{c}\text { Hand hygiene } \\
\text { and control } \\
\text { group }\end{array}$ & $\begin{array}{c}\text { The percentage } \\
\text { of the total } \\
\text { absent days and } \\
\text { percentage of } \\
\text { illness-related } \\
\text { absent days }\end{array}$ & $\begin{array}{l}\text { The low } \\
\text { percentage of } \\
\text { absenteeism } \\
\text { could be } \\
\text { associated with } \\
\text { the use of hand } \\
\text { hygiene }\end{array}$ \\
\hline $\begin{array}{l}\text { Salvolainen- } \\
\text { Kopra et al., } \\
2012\end{array}$ & $\begin{array}{c}21 \text { clusters in } 6 \\
\text { companies in } \\
\text { Helsinki, } \\
\text { Finland }\end{array}$ & 683 employees & $\begin{array}{c}\text { Cluster- } \\
\text { randomized } \\
\text { intervention } \\
\text { trial }\end{array}$ & $\begin{array}{l}\text { Hand hygiene } \\
\text { with soap and } \\
\text { water, alcohol } \\
\text { rub, and control } \\
\text { group }\end{array}$ & $\begin{array}{l}\text { Infection } \\
\text { episodes }\end{array}$ & $\begin{array}{c}\text { Significant } \\
\text { reduction of } \\
\text { infection } \\
\text { episodes in } \\
\text { hand hygiene } \\
\text { with soap arm } \\
\text { compared with } \\
\text { alcohol rub and } \\
\text { control group } \\
\text { arm } \\
\end{array}$ \\
\hline
\end{tabular}




\begin{tabular}{|c|c|c|c|c|c|c|}
\hline $\begin{array}{c}\text { Simmerman et } \\
\text { al., } 2011\end{array}$ & $\begin{array}{l}\text { The outpatient } \\
\text { department of } \\
\text { the Queen } \\
\text { Sirikit National } \\
\text { Institute of } \\
\text { Child Health } \\
\text { (QSNICH) in } \\
\text { Bangkok }\end{array}$ & 1589 households & $\begin{array}{l}\text { Randomized } \\
\text { controlled trial }\end{array}$ & $\begin{array}{l}\text { Hand hygiene, } \\
\text { hand hygiene } \\
\text { plus surgical } \\
\text { face mask, and } \\
\text { control group }\end{array}$ & $\begin{array}{c}\text { Secondary } \\
\text { influenza } \\
\text { infection cases }\end{array}$ & $\begin{array}{l}\text { No significant } \\
\text { difference } \\
\text { between } \\
\text { intervention } \\
\text { groups }\end{array}$ \\
\hline $\begin{array}{c}\text { Stebbins et al., } \\
2011\end{array}$ & $\begin{array}{l}10 \text { elementary } \\
\text { schools in } \\
\text { Pittsburgh, USA }\end{array}$ & 3360 students & $\begin{array}{l}\text { Randomized } \\
\text { controlled trial }\end{array}$ & $\begin{array}{l}\text { Hand hygiene, } \\
\text { cough etiquette, } \\
\text { and control } \\
\text { group }\end{array}$ & $\begin{array}{c}\text { Total } \\
\text { absenteeism } \\
\text { episodes and } \\
\text { laboratory- } \\
\text { confirmed cases } \\
\text { of influenza }\end{array}$ & $\begin{array}{l}\text { No significant } \\
\text { differences in } \\
\text { laboratory- } \\
\text { confirmed cases, } \\
\text { but there was a } \\
\text { reduction in } \\
\text { total } \\
\text { absenteeism } \\
\text { episodes }\end{array}$ \\
\hline Suess et al., 2012 & $\begin{array}{l}\text { Recruited by the } \\
\text { general } \\
\text { practitioner and } \\
\text { pediatrician in } \\
\text { Berlin, Germany }\end{array}$ & 84 households & $\begin{array}{c}\text { Cluster- } \\
\text { randomized } \\
\text { controlled trial }\end{array}$ & $\begin{array}{l}\text { Hand hygiene, } \\
\text { face mask, and } \\
\text { control group }\end{array}$ & $\begin{array}{c}\text { Secondary } \\
\text { infection cases }\end{array}$ & $\begin{array}{c}\text { Significant } \\
\text { reductions of } \\
\text { infections in the } \\
\text { intervention } \\
\text { group compared } \\
\text { with the control } \\
\text { group }\end{array}$ \\
\hline $\begin{array}{c}\text { Talaat et al., } \\
2011\end{array}$ & $\begin{array}{c}60 \text { elementary } \\
\text { schools in Cairo, } \\
\text { Egypt }\end{array}$ & 20882 students & $\begin{array}{l}\text { Randomized } \\
\text { controlled trial }\end{array}$ & $\begin{array}{l}\text { Hand hygiene } \\
\text { and control } \\
\text { group }\end{array}$ & $\begin{array}{l}\text { Laboratory- } \\
\text { confirmed } \\
\text { influenza and } \\
\text { the number of } \\
\text { absenteeism } \\
\text { caused by ILI }\end{array}$ & $\begin{array}{l}\text { Significant } \\
\text { decrease in the } \\
\text { intervention } \\
\text { group compared } \\
\text { with the control } \\
\text { group }\end{array}$ \\
\hline
\end{tabular}

Table 3. Summary of the two articles under patient and contact management.

\begin{tabular}{|c|c|c|c|c|c|c|}
\hline Study & Setting & $\begin{array}{c}\text { Participants and } \\
\text { follow-up }\end{array}$ & Study design & $\begin{array}{c}\text { Interventions } \\
\text { evaluated }\end{array}$ & Main outcomes & Findings \\
\hline Hsieh et al., 2007 & $\begin{array}{c}\text { SARS outbreak } \\
\text { in Taiwan }\end{array}$ & Community & $\begin{array}{l}\text { Observational } \\
\text { study }\end{array}$ & $\begin{array}{c}\text { Quarantine } \\
\text { Level A: people } \\
\text { with potential } \\
\text { contacts with } \\
\text { suspected SARS } \\
\text { patients } \\
\text { Quarantine } \\
\text { Level B: people } \\
\text { traveling from } \\
\text { the SARS area }\end{array}$ & $\begin{array}{l}\text { Number of } \\
\text { SARS cases and } \\
\text { mortality }\end{array}$ & $\begin{array}{c}\text { Level A } \\
\text { quarantine } \\
\text { could be } \\
\text { associated with } \\
\text { the prevention } \\
\text { of } \\
\text { approximately } \\
461 \text { additional } \\
\text { SARS cases and } \\
62 \text { additional } \\
\text { deaths as } \\
\text { compared with } \\
\text { Level B } \\
\text { quarantine }\end{array}$ \\
\hline
\end{tabular}




\begin{tabular}{|c|c|c|c|c|c|c|}
\hline $\begin{array}{l}\text { Wang et al., } \\
2007\end{array}$ & $\begin{array}{l}\text { SARS outbreak } \\
\text { in Taiwan }\end{array}$ & Community & $\begin{array}{l}\text { Observational } \\
\text { study }\end{array}$ & $\begin{array}{c}\text { Quarantine } \\
\text { Levels A \& B (as } \\
\text { above) }\end{array}$ & $\begin{array}{l}\text { Identifying } \\
\text { people who fit } \\
\text { the criteria for } \\
\text { quarantine }\end{array}$ & $\begin{array}{c}\text { Quarantining } \\
\text { people with } \\
\text { known exposure } \\
\text { to persons } \\
\text { infected with } \\
\text { SARS could } \\
\text { have reduced } \\
\text { the number of } \\
\text { persons } \\
\text { quarantined by } \\
\text { approximately } \\
64 \%\end{array}$ \\
\hline
\end{tabular}

Table 4. Summary of the two articles under community restriction.

\begin{tabular}{|c|c|c|c|c|c|c|}
\hline Study & Setting & $\begin{array}{l}\text { Participants and } \\
\text { follow-up }\end{array}$ & Study design & $\begin{array}{c}\text { Interventions } \\
\text { evaluated }\end{array}$ & Main outcomes & Findings \\
\hline Effler et al., 2010 & $\begin{array}{c}\text { Elementary } \\
\text { chools in Perth, } \\
\text { Australia }\end{array}$ & 233 parents & $\begin{array}{l}\text { Observational } \\
\text { study }\end{array}$ & School closure & $\begin{array}{l}\text { Survey on } \\
\text { family } \\
\text { preparedness } \\
\text { and impact } \\
\text { during the } \\
\text { closure of the } \\
\text { school }\end{array}$ & $\begin{array}{c}47 \% \text { thought the } \\
\text { school closure } \\
\text { was } \\
\text { appropriate, } \\
33 \% \text { thought it } \\
\text { was } \\
\text { inappropriate, } \\
\text { and } 20 \% \text { remain } \\
\text { unknown }\end{array}$ \\
\hline $\begin{array}{c}\text { Heymann et al., } \\
2009\end{array}$ & $\begin{array}{c}\text { Israel } \\
\text { nationwide } \\
\text { elementary } \\
\text { schools }\end{array}$ & $\begin{array}{c}\text { Children (6-12 } \\
\text { years) } \\
\text { Household } \\
\text { members } \\
\text { aged }>12 \text { years } \\
\text { presumed to be } \\
\text { living with these } \\
\text { children and all } \\
\text { other Maccabi } \\
\text { members }\end{array}$ & $\begin{array}{c}\text { Observational } \\
\text { study }\end{array}$ & School closure & $\begin{array}{c}\text { The weekly ratio } \\
\text { of ILI diagnoses } \\
\text { to non- } \\
\text { respiratory } \\
\text { diagnoses }\end{array}$ & $\begin{array}{l}\text { The weekly ratio } \\
\text { of ILI diagnoses } \\
\text { to non- } \\
\text { respiratory } \\
\text { diagnoses was } \\
\text { statistically } \\
\text { significant for } \\
\text { school children }\end{array}$ \\
\hline
\end{tabular}

Table 5. Summary of articles under the combined non-pharmaceutical intervention.

\begin{tabular}{|c|c|c|c|c|c|c|}
\hline Study & Setting & $\begin{array}{l}\text { Participants and } \\
\text { follow-up }\end{array}$ & Study design & $\begin{array}{c}\text { Interventions } \\
\text { evaluated }\end{array}$ & Main outcomes & Findings \\
\hline Bartlett, 2004 & $\begin{array}{l}\text { SARS outbreak } \\
\text { in Beijing, China }\end{array}$ & $\begin{array}{l}2521 \text { probable } \\
\text { cases }\end{array}$ & $\begin{array}{c}\text { Observational } \\
\text { study }\end{array}$ & $\begin{array}{l}\text { Quarantine, } \\
\text { closure of } \\
\text { facilities, and } \\
\text { transit site } \\
\text { screening }\end{array}$ & $\begin{array}{l}\text { Attack rate and } \\
\text { number of } \\
\text { probable cases }\end{array}$ & $\begin{array}{l}\text { The multiple } \\
\text { control } \\
\text { measures } \\
\text { implemented in } \\
\text { Beijing likely led } \\
\text { to the rapid } \\
\text { resolution of the } \\
\text { SARS outbreak }\end{array}$ \\
\hline
\end{tabular}




\begin{tabular}{|c|c|}
\hline NPIs & Non-pharmaceutical interventions \\
\hline PRISMA & $\begin{array}{c}\text { Preferred Reporting Items for Systematic Reviews } \\
\text { and Meta-Analyses }\end{array}$ \\
\hline SARS-CoV-2 & Severe Acute Respiratory Syndrome Coronavirus 2 \\
\hline WHO & World Health Organization \\
\hline PHEIC & Public Health Emergency of International Concern \\
\hline PPE & Personal Protective Equipment \\
\hline ILI & Influenza-Like Illnesses \\
\hline $\mathrm{MeSH}$ & Medical Subject Headings \\
\hline $\mathrm{CDC}$ & Centers for Disease Control and Prevention \\
\hline SARI & Severe Acute Respiratory Infection \\
\hline
\end{tabular}

Supplementary Materials: The following are available online at https://drive.google.com/drive/folders/1XuNBUqe8cJp77-

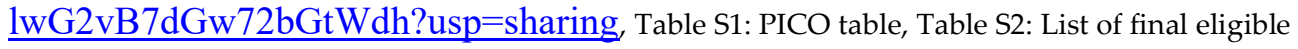
articles.

Author Contributions: Conceptualization, S.P.C, N.M \& F.D; methodology, S.P.C \& N.M; validation, S.P.C \& N.M.; formal analysis, S.P.C \& N.M; resources, S.P.C \& N.M; data curation, S.P.C \& N.M; writing-original draft preparation, S.P.C \& N.M.; writing - review and editing, S.P.C, N.M \& F.D; visualization, S.P.C \& N.M.; supervision, F.D.; project administration, F.D; funding acquisition, F.D. All authors have read and agreed to the published version of the manuscript.

Funding: This work receives funding from the National University of Malaysia under research code GUP-2019-080.

Acknowledgments: The authors would like to thank the Department of Community Health, Faculty of Medicine, University Kebangsaan Malaysia for providing helpful insights on study design and critiques of the manuscript drafts. Besides that, the authors would also like to acknowledge the Dean of Faculty of Medicine, University Kebangsaan Malaysia, and the Director-General of Health, Malaysia.

Conflicts of Interest: The authors declare no conflict of interest.

\section{References}

1. Worldometer. COVID-19 Coronavirus Pandemic. Worldometer. Accessed 4th June 2020 , 2020. https://www.worldometers.info/coronavirus/

2. WHO. COVID-19 Public Health Emergency of International Concern (PHEIC) Global research and innovation forum. 2020. Accessed 4th June 2020, 2020. https://www.who.int/who-documents-detail/covid-19-public-health-emergency-of-international-concern-(pheic)-globalresearch-and-innovation-forum

3. Qualls N, Levitt A, Kanade N, Wright-Jegede N, Dopson S, Biggerstaff M. Community mitigation guidelines to prevent pandemic influenza-United States, 2017. MMWR Recomm Reports. 2017;66(1)

4. Aiello AE, Perez V, Coulborn RM, Davis BM, Uddin M, Monto AS. Facemasks, hand hygiene, and influenza among young adults: A randomized intervention trial. PLoS One. 2012;7(1)

5. Lockwood C, Munn Z, Porritt K. Qualitative research synthesis: methodological guidance for systematic reviewers utilizing metaaggregation. JBI Evidence Implementation. 2015;13(3)

6. Moher D, Liberati A, Tetzlaff J, Altman DG, Group P. Preferred reporting items for systematic reviews and meta-analyses: the PRISMA statement. PLoS med. 2009;6(7):e1000097.

7. Aledort JE, Lurie N, Wasserman J, Bozzette SA. Non-pharmaceutical public health interventions for pandemic influenza: An evaluation of the evidence base. BMC Public Health. 2007;7(1)

8. Apisarnthanarak A, Apisarnthanarak P, Cheevakumjorn B, Mundy LM. Intervention with an Infection Control Bundle to Reduce Transmission of Influenza-Like Illnesses in a Thai Preschool. Infect Control Hosp Epidemiol. 2009;30(9):817-22-817-22.

9. Cowling BJ, Chan KH, Fang VJ, Cheng CKY. Annals of Internal Medicine Article Facemasks and Hand Hygiene to Prevent Influenza Transmission in Households. Ann Intern Med. 2009;151):437-46

10. Potter LA, Scholze DA, Biag HMB, Schneider A, Chen Y, Nguyen D V. A Randomized Controlled Trial of Sertraline in Young Children With Autism Spectrum Disorder. Front psychiatry [Internet. 2019;10

11. Lau CH, Springston EE, Sohn MW, Mason I, Gadola E, Damitz M. Hand hygiene instruction decreases illness-related absenteeism in elementary schools: a prospective cohort study. BMC Pediatr; 2012.

12. Simmerman JM, Suntarattiwong P, Levy J, Jarman RG, Kaewchana S, Gibbons R V. Findings from a household randomized controlled trial of hand washing and face masks to reduce influenza transmission in Bangkok, Thailand. Influenza Other Respi Viruses. 2011;5(4):256-67256-67.

13. Suess T, Remschmidt C, Schink SB, Schweiger B, Nitsche A, Schroeder K. The role of facemasks and hand hygiene in the prevention of influenza transmission in households: Results from a cluster randomised trial. 2009. 
14. Stebbins S, Downs JS, Vukotich CJ. Using nonpharmaceutical interventions to prevent influenza transmission in elementary school children: Parent and teacher perspectives. J Public Heal Manag Pract. 2009;15(2):112-17-112-17.

15. Talaat M, Afifi S, Dueger E, El-Ashry N, Marfin A, Kandeel A. Effects of hand hygiene campaigns on incidence of laboratory-confirmed influenza and absenteeism in schoolchildren, Cairo, Egypt. Emerg Infect Dis. 2011;17(4)

16. Savolainen-Kopra C, Haapakoski J, Peltola PA, Ziegler T, Korpela T, Anttila P. Hand washing with soap and water together with behavioural recommendations prevents infections in common work environment: An open cluster-randomized trial. Trials. 2012;

17. Hsieh YH, King CC, Chen CWS, Ho MS, Hsu SB, Wu YC. Impact of quarantine on the 2003 SARS outbreak: A retrospective modeling study. J Theor Biol. 2007;244(4):729-36-729-36.

18. Larson EL, Ferng YH, Wong-McLoughlin J, Wang S, Haber M, Morse SS. Impact of non-pharmaceutical interventions on URIs and influenza in crowded, urban households. Public Health Rep. 2010;125(2):178-91-178-91.

19. Heymann AD, Hoch I, Valinsky L, Kokia E, Steinberg DM. School closure may be effective in reducing transmission of respiratory viruses in the community. Epidemiol Infect. 2009;

20. Effler P V, Carcione D, Giele C, Dowse GK, Goggin L, Mak DB. Household responses to pandemic (H1N1) 2009-related school closures, Perth, Western Australia. Emerg Infect Dis. 2010;16(2):205-11-205-11.

21. Bartlett JG. Effect of antibacterial home cleaning and handwashing products on infectious disease symptoms: A randomized, double-blind trial. Infect Dis Clin Pract. 2004;12(4)

22. Brankston G, Gitterman L, Hirji Z, Lemieux C, Gardam M. Transmission of influenza A in human beings. 2007.

23. Leung GM, Ho LM, Chan SKK, Ho SY, Bacon-Shone J, Choy RYL. Longitudinal assessment of community psychobehavioral responses during and after the 2003 outbreak of severe acute respiratory syndrome in Hong Kong. Clin Infect Dis. 2005;40(12):1713-20-1713-20.

24. Alert E. RESPONSE WHO checklist for influenza pandemic preparedness planning. 2005.

25. Your G, Ready C, Flu P. Get Your Community Ready for Pandemic Influenza Using Nonpharmaceutical Interventions. 2017. 